\title{
MEDIA REAL TRADING SEBAGAI PELATIHAN YANG EFEKTIF UNTUK MEMULAI BERINVESTASI SAHAM
}

\author{
Saptani Rahayu ${ }^{a^{*}}$, Indriyana Widyastuti ${ }^{a}$, Nugroho Wisnu Murti ${ }^{a}$ \\ ${ }^{a}$ Sekolah Tinggi Ilmu Ekonomi Adi Unggul Bhirawa Surakarta \\ *yayuksaptani@gmail.com
}

\begin{abstract}
ABSTRAK
Program Pengabdian kepada Masyarakat ini mengangkat tema memasyarakatkan budaya Investasi pada Instrumen Investasi jenis Pasar Saham. Urgensi pelaksanaan tersebut adalah fakta bahwa investasi pada saham belum menjadi pilihan favorit di Indonesia. Terkait dengan kondisi tersebut, Bursa Efek Indonesia (BEI) memiliki program khusus dengan perguruan tinggi dalam rangka meningkatkan ketertarikan terhadap investasi di pasar modal melalui media pendidikan. Galeri Investasi BEI Sekolah Tinggi Ilmu Ekonomi AUB Surakarta sebagai salah satu Galeri Perguruan Tinggi BEI pertama di Surakarta beberapa kali menyelenggarakan pelatihan gratis dan simulasi trading saham yang diikuti dari berbagai kalangan dan profesi. Informasi program pengabdian yang disampaikan pada artikel ini adalah pelaksanaan pelatihan yang dilakukan tidak sebatas pada simulasi, tetapi dengan real trading. Media real trading pelatihan memberikan fasilitas akun investasi dalam jumlah dana investasi tertentu yang dapat digunakan oleh peserta pelatihan untuk digunakan bertransasksi saham mengukuti dinamika pasar saham secara real time. Pelatihan dilaksanakan selama dua hari yang dibagi dalam dua sesi dengan menyesaikan jam perdagangan di pasar regular saham Indonesia. Manfaat atas kegiatan tersebut adalah ketertarikan dan kesiapan investor baru untuk masuk dalam kegitan transaksi di pasar saham. Peserta yang awalnya tidak memahami tentang kegiatan pasar modal sebagai instrument Investasi, menjadi memahami dan melakukan pembuatan Rekening Dana Nasabah (RDN) sebagai indicator capaian output program pengabdian kepada msayarakat. Fasilitas untuk membuat RDN dengan nilai yang sangat terjangkau, memberikan peluang lebih besar untuk memulai berinvestasi saham. Berdasarkan hasil yang pelaksanaan kegiatan ini, media real trading dalam pelatihan berinvestasi saham merupakan media yang efektif untuk dilakukan dengan mempertimngkan capaian hasil pembentukan Rekening Dana Nasahan sebesar $76 \%$ dari target pembentukan RDN dari peserta pelatihan.
\end{abstract}

Kata Kunci: Pelatihan, Real Trading, Saham, Galeri Investasi.

\section{PENDAHULUAN}

Instrumen investasi yang diminati di Indonensia dan diyakini memiliki daya tahan tinggi adalah tanah, property dan emas. Hal tersebut biasanya dibandingkan dengan instrument lain semacam bunga deposito dan tabungan yang tidak dapat mengikuti peningkatan inflasi yang selalu mengalami kenaikan. Akan tetapi. Instrument investasi sejenis surat berharga antara lain yaitu saham dan obligasi belum menjadi pilihan utama. Berapa pihak memiliki persepsi bahwa kepemilikan saham seolah kekayaan yang tidak nyata, dan ada juga yang memiliki anggapan bahwa investasi saham hampir sama dengan judi. Persepsi ini yang dimungkinkan masih menjadi penyebab kurangnya minat berinvestasi saham di Indonesia dibandingkan dengan negara lain di Asia, meskipun Indonesia telah memiliki peningkatan terbesar atas return saham didunia selama sepuluh tahun tahun terakhir sampai dengan tahun 2015. Return saham di Indonesia mencapai tingkat tertinggi di banding negara lain selama sepuluh tahun terkahir yang ditunjukkan pada Gambar 1. Perbandingngan berbagai intrumen investasi saham dengan yang lain di Indonesia dapat ditunjukkan pada Gambar 2. Gambar 1 menunjukkan bahwa saham merupakan istrumen investasi yang memiliki peningkatan valuasi tertinggi diantara instrument yang lain. 


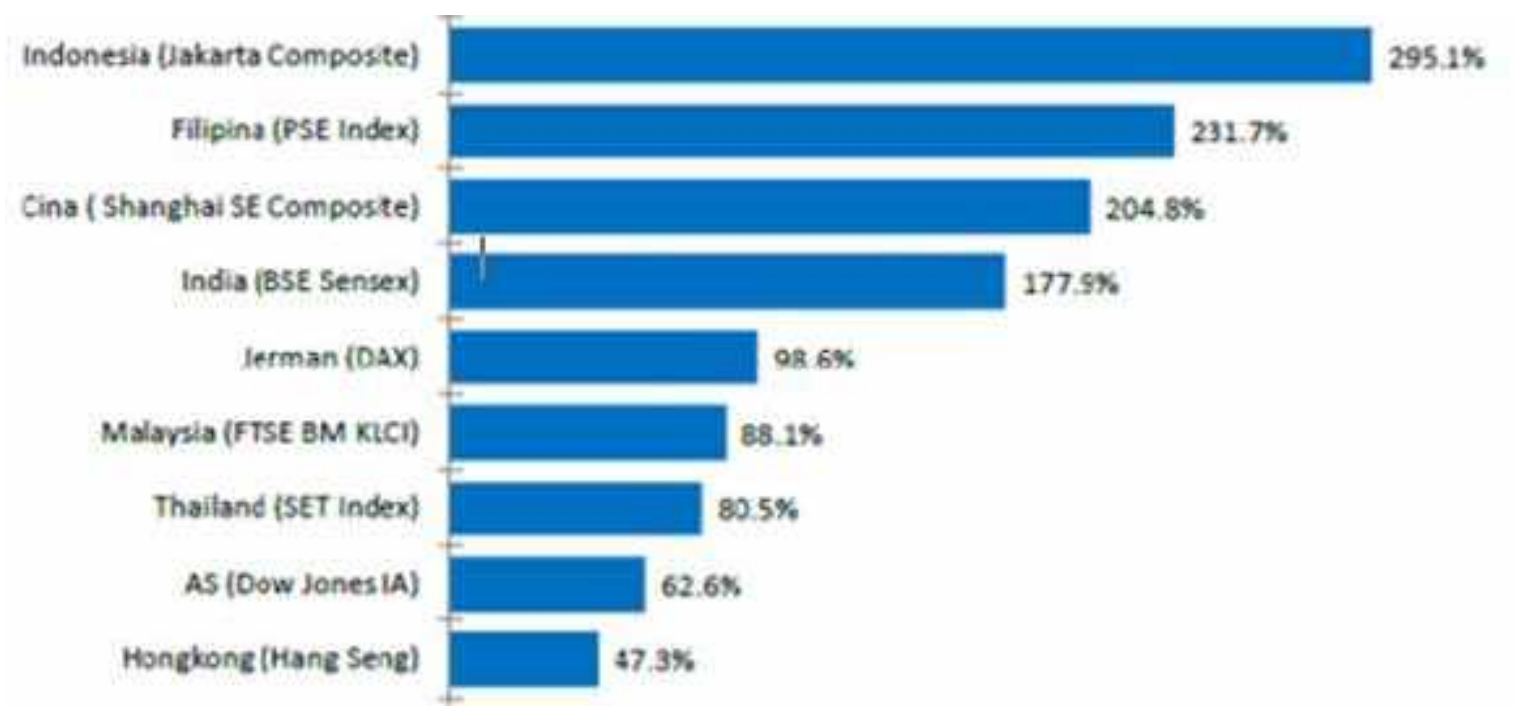

Gambar 1. Perbandingan peningkatan return saham 10 tahun terakhir seblum tahun 2015

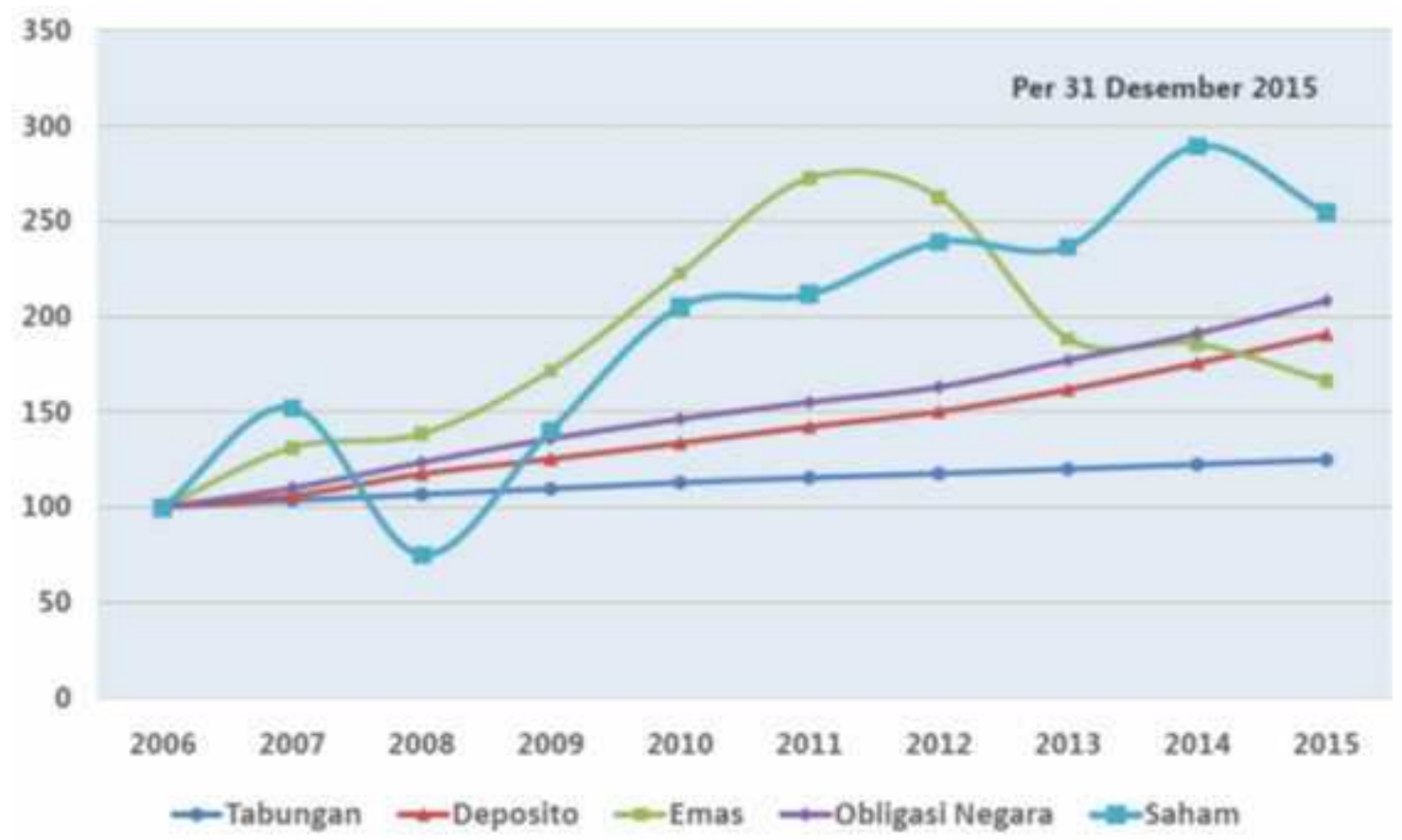

Sumber:www.idx.co.id

Gambar 2. Perbandingan fluktuasi nilai investasi diIndonesia

Capaian tersebut tidak terlepas dari program unggulan Bursa Efek Indonesia yang membentuk Galeri Investasi di setiap Perguruan Tinggi di Indonesia sebagai mitra dalam edukasi investasi di pasar modal Indonesia. Selain faktor tersebut, kebijakan BEI yang semakin memberikan ruang bagi calon investor dengan dengan tingkat Investasi yang sangat terjangkau, memberikan peluang bagi semua kalangan untuk melakukan investasi di pasar saham. Salah satu program unggulan yang ditujukan khusus bagai perguruan tinggi adalah "Sahamku 100ribu”. Program ini memberikan peluang bagi mahasiswa untuk sangat terjangkau memulai belajar berinvestasi.

Akan tetapi, persepsi tentang saham adalah judi masih banyak terjadi, bahkan persepsi tersebut terkadang berasal dari lingkungan perguruaan tinggi. Persepsi tersebut dimungkinkan muncul dari istilah yang sering digunakan dengan kata "bermain saham". Istilah tersebut cukup sulit untuk 
dihilangkan dari komunikasi umum di masyarakat. Dengan demikian, salah satu tujuan kegiatan pelatihan berinvestasi di pasar saham ini adalah mengembalikan pengertian saham sebagai intrumen berinvestasi, bukan bermain atau yang sering disebut sebagai judi. Selain itu, Strategi dan cara analisis untuk mengurangi resiko kerugian dan meningkatkan peluang untuk mendapatkan keuntungan dalam membeli intrumen saham, juga disampaikan dalam pelatihan ini. Output utama yang dicapai sebagai indicator program pengabdian pengabdian ini adalah jumlah peserta dan pendaftaran sampai dengan membentuk Rekening Dana Nasabah. Target capaian peserta adalah 20 peserta pada setiap sesi dan $30 \%$ dari jumlah peserta membetuk Rekening Danna Nasabah untuk memulai berinvestasi saham.

\section{METODE}

Metode penyampaian materi pada program pengabdian masyarakat ini adalah

pelatihan. Pelatihan merupakan proses sistematis untuk mengubah tingkah laku anggota organisasi untuk mencapai tujuan organisasi (Rivai, 2005 , p. 225). Lebih lanjut dijelaskan bahwa pelatihan berkatian dengan keahlian dan kemampuan untuk melaksanakan pekerjaan saat ini dan memiliki orientasi saat ini untuk mencapai keahlian serta kemampuan tertentu dalam melaksanakan pekerjaan. Pengertian sejenis tentang pelatihan dijelaskan bahwa pelatihan merupakan proses belajar mengajar dengan menggunakan teknik tertentu secara konsepsional untuk meningkatkan keterampilan dan kemampuan kerja (Lubis, 2008, p. 7). Dua pengertian diatas diadopsi sebagai metode dalam pengabdian kepada masyarakat ini dengan menggunakan media real trading. Real trading yang dimaksud adalah penggunaan transasksi riil perdagangan pada aktifitas pasar saham khususnya di Indonesia. Peserta pelatihan diberikan fasilitas akun investasi yang dapat ditransasksikan secara langsung pada pasar saham dan mengikuti pergerakan real time aktifitas harga saham di Indonesia.

Pemateri pelatihan adalah tim intruktur yang terdiri dari konsultan investasi dari perusahaan sekuritas dan beberapa dosen dari STIE AUB. Tim ini diperlukan dalam rangka pendampingan langsung saat perserta mengikuti pelatihan dengan menggunakan fasilitas komputer di Galeri Investasi STIE AUB. Proses perekrutan peserta pelatihan menggunakan media online bahwa peserta diminta untuk mendaftarkan diri sebagai peserta melalui link tertentu dengan menggunakan survey gizmo. Pemberitahuan untuk penerimaan sebagai peserta pelatihan yang dilakukan secara gratis ini dilakukan melalui e-mail yang dapat diketahui saat pengisian formulir pendaftaran secara elektronik. Pelatihan dengan lembar kerja peserta berupa hasil perdagangan saham dalam jangka pendek ini seringkali secara umum disebut sebagai workshop.

\section{HASIL DAN PEMBAHASAN}

Alur pelatihan yang dilaksanakan dalam pelaksanaaan program pengabdian masyarakat ini dapat ditunjukan pada Gambar 3. Konsultan investasi yang memberikan pelatihan berasal dari perusahaan securitas PT. Reliance Securitas. Pelatihan dilaksanakan selama dua hari yang terdiri dari hari pertama sebagai gambaran umum tentang cara berinvestasi dan trading saham di Indonesia. Praktek jual beli saham termasuk strategi mengeola resiko dan memberikan peluang lebih besar untuk mendapatkan keuntungan disampaikan pada hari kedua. Peserta pelatihan dibagi dalam dua kelompok dengan mempertimbangkan efektifitas penyampaian materi dan keterbatsasn fasilitas komputer. Satu kelompok terdiri dari maksimal 22 peserta yang dibagi dalam dua sesi yang menyesuaikan perdagangan di pasar saham Indonesia. Aktifitas pasar saham di Indonesia dibagi dalam dua sesi yaitu Sesi 1 (9.00 12.00

WIB) dan Sesi 2 (13.30 - 16.00 WIB). Detail pembagian sesi ini sangat penting diketahui oleh trader dan investor untuk mempersiapkan perdagangan saham. Pembagian sesi tersebut ditunjukan pada Tabel 1 . 


\section{Materi}

1. Peluang Trading dan Investasi di Pasar Modal khususnya saham

2. Tehnik analisis trading dan investasi (Mengurangi resiko rugi dan menambah peluang keuntungan)

3. Praktek (real transaction) Jual Beli saham jangka pendek

Fasilitas:
Ilmu yeng bermanfaat
Sertifikat
Alun invertasi saham
gonus saldo akun investasi saham
Snack
Seminar kit
free

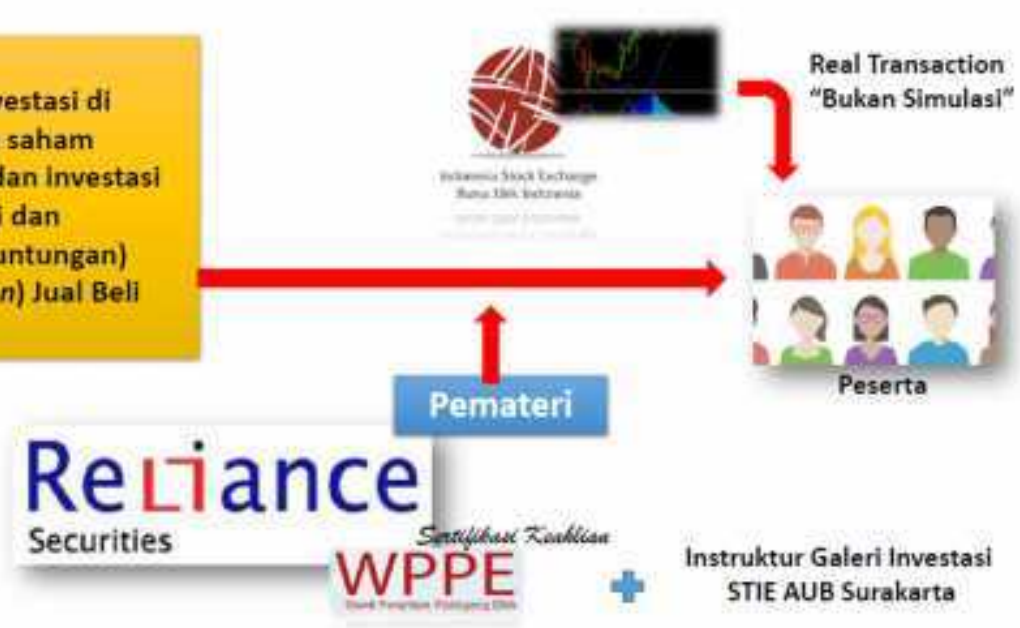

Gambar 3. Alur pelaksanaan pelatihan trading saham

Tabel 1. Sesi Perdagangan Saham di Indonesia sebagai penyesuain jadwal pelaksanaan pelatihan

\begin{tabular}{|l|l|l|}
\hline $\begin{array}{l}\text { PRE-OPENING } \\
\text { Senin-Jumat }\end{array}$ & $08.45-08.55$ WIB & $\begin{array}{l}\text { AB dapat memasukkan order jual/beli namun } \\
\text { tidak ada transaksi yang terjadi. }\end{array}$ \\
\cline { 2 - 3 } & $08.55-09.00$ WIB & $\begin{array}{l}\text { Berdasarkan harga order jual/bell yang } \\
\text { dimasukkan, sistem JATS akan menetapkan } \\
\text { Opening Price saham. }\end{array}$ \\
\hline $\begin{array}{l}\text { TRADING SESSION } \\
\text { Senin-Kamis } \\
\text { Jumat }\end{array}$ & $\begin{array}{l}\text { Sesil } \\
09.00-12.00 \text { WIB } \\
09.00-11.30 \text { WIB }\end{array}$ & $\begin{array}{l}\text { Sesill } \\
13.30-15.49 \text { WIB } \\
14.00-15.49 \text { WIB }\end{array}$ \\
\hline $\begin{array}{l}\text { PRE-CLOSING } \\
\text { Senin-Jumat }\end{array}$ & $15.50-16.00$ WIB & $\begin{array}{l}\text { AB dapat memasukkan order jual/beli namun } \\
\text { tidak ada transaksi yang terjadi. }\end{array}$ \\
\cline { 2 - 3 } & $16.00-16.05$ WIB & $\begin{array}{l}\text { Berdasarkan harga order jual/beli yang } \\
\text { dimasukkan, sistem JATS akan menetapkan } \\
\text { Closing Price saham. }\end{array}$ \\
\hline $\begin{array}{l}\text { POST TRADING } \\
\text { Senin-Jumat }\end{array}$ & $16.05-16.15$ WIB & $\begin{array}{l}\text { Order dimasukkan pada harga Closing Price dan } \\
\text { transaksi terjadi berdasarkan Time Priority }\end{array}$ \\
\hline
\end{tabular}

Sumber: $\underline{w w w . i d x . c o . i d}$

Aplikasi perdagangan yang digunakan dalam pelatihan ini adalah aplikasi saham dari perusahaan securitas PT. Raliance Securitas. Pemilihan mitra ini mempertimbangkan mitra Anggota Bursa Galeri Investasi STIE AUB Surakarta sebagai lokasi pelaksanaan pelatihan. Selain itu, fasilitas serta aplikasi remote trading yang diberikan dari PT. Reliance Securitas mengandung fasilitas informasi fundamental dan technical sebagai media melakukan analisis trading dan invertase yang diperlukan oleh trader dan investor. Mekanisme remote trading dapat ditunjukan pada Gambar 4. Remote trading adalah fasilitas yang diberikan oleh perusahaan securitas kepada investor dan trader untuk dapat melakukan transaksi secara personal berdasarkan analisis yang diyakini oleh setiap 
investor. Setiap trader dan investor harus mengetahui mekanisme tersebut untuk memberikan keputusan jenis investasi pada saham dan jumlah yang yang beragam.
Keberagaman tersebut yang membentuk dinamika pasar yang berupa fluktuasi harga saham yang selalu berubah

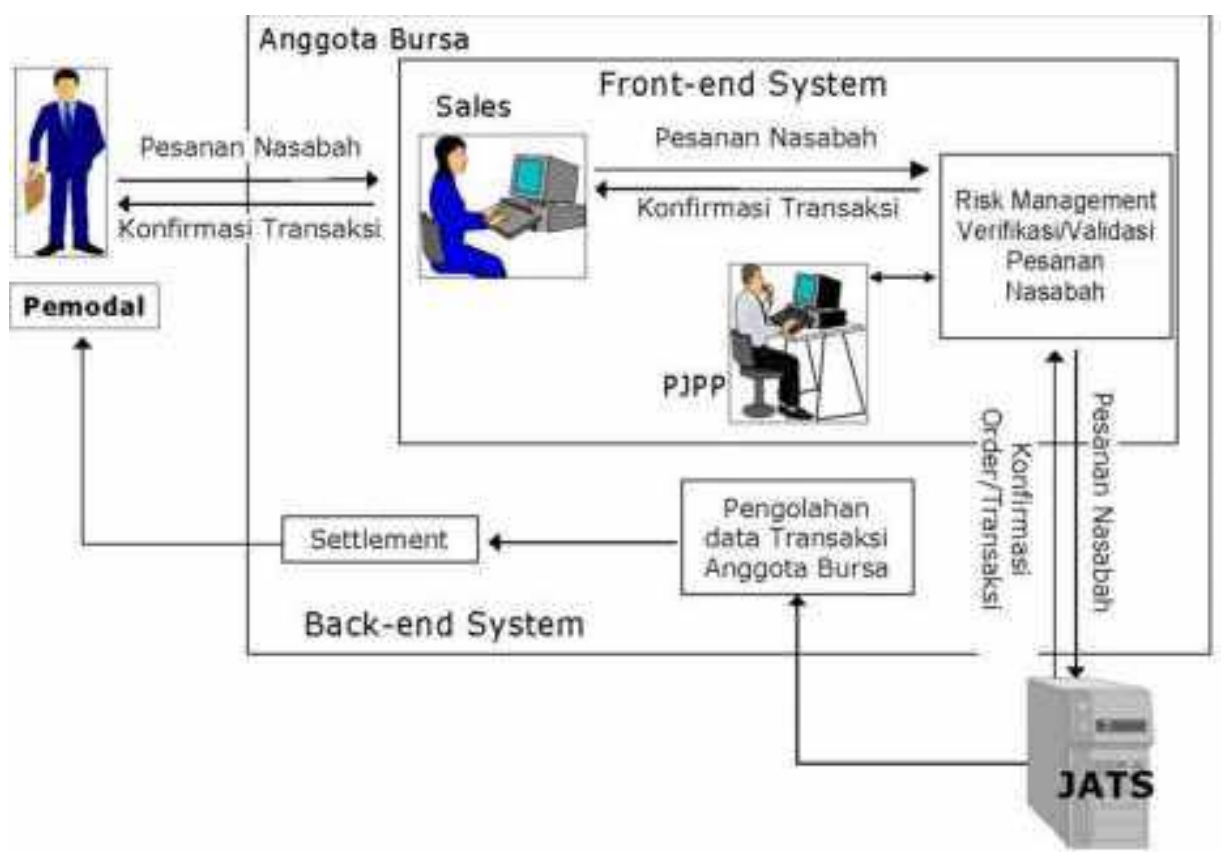

Gambar 4. Mekanisme remote trading yang perlu dipahami investor dan trader untuk mengetahui bahwa perdagangan dapat dilakukan sendiri dan dijamin keamanan transaksinya

Aktivitas perdagangan di pasar saham seolah memiliki berbagai istilah yang cukup sulit diingat dan juga dipahami oleh investor pemula ataupun trader. Dengan demikian, pelatihan ini membantu peserta untuk mengenal hal pokok yang perlu diketahui dalam memulai investasi dengan menyederhanakan berbagai istilah pasar saham yang mungkin tidak dikenal oleh masyarakat umum. Tahapan terdiri dari pengenalan pasar saham sebagai intrumen investasi sampai dengan praktek pelaksanaan riil trading dengan fasilitas akun yang disediakan. Alus materi yang disampaikan selama dua hari tersebut ditunjukan pada Gambar 5

Gambar 5. Alur materi yang disam paikan dalam pelatihan

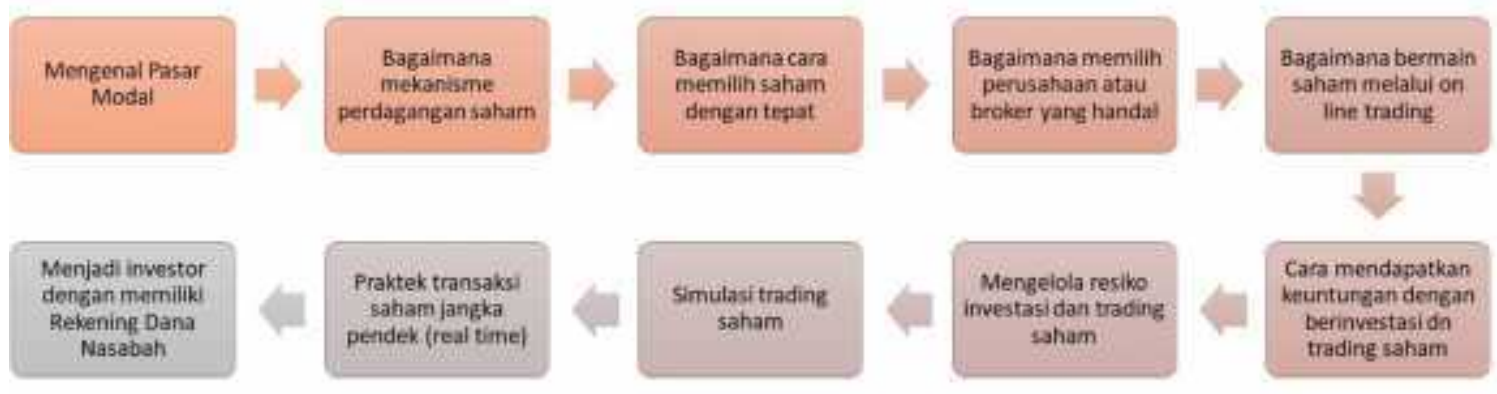

Total perserta yang mengikuti kegiatan pelatihan selama dua sesi dalam dua hari memiliki jumlah peserta yang berbeda. Hari pertama pelatihan dengan materi mengenal pasar modal dan juga simulasi yang diikuti 


\section{Vol.3, No.1 (2019) ; p.24-31 ; https://e-journal.stie-aub.ac.id/index.php/wasana nyata}

sebanyak 38 peserta dalam dua sesi. Hari kedua pelatihan diikuti sebanyak 43 peserta untukdua sesi. Dengan demikian media praktek riil trading yang dilaksanakan pada hari kedua menjadi daya tarik khusus sebagai metode pelatihan yang tidak biasa dilakukan dalam pelatihan pasar saham. Peserta pelatihan
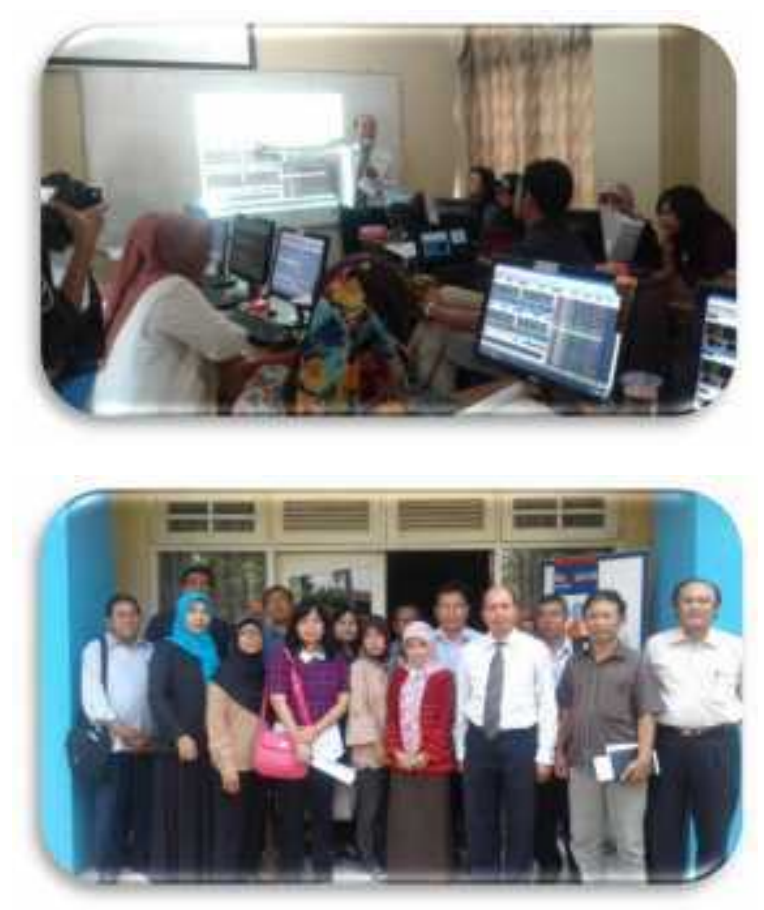

terdiri dari berbagai latar belakang pendidikan dan profesi antara lain dosen, mahasiswa, pegawai negeri sipil, dan pegawai swasta diwilayah karesidenan Surakarta. Proses pelaksanaan pelatihan tersebut dapatn ditunjukan beberapa dokumentasi pelaksanaan pelatihan pada Gambar 6
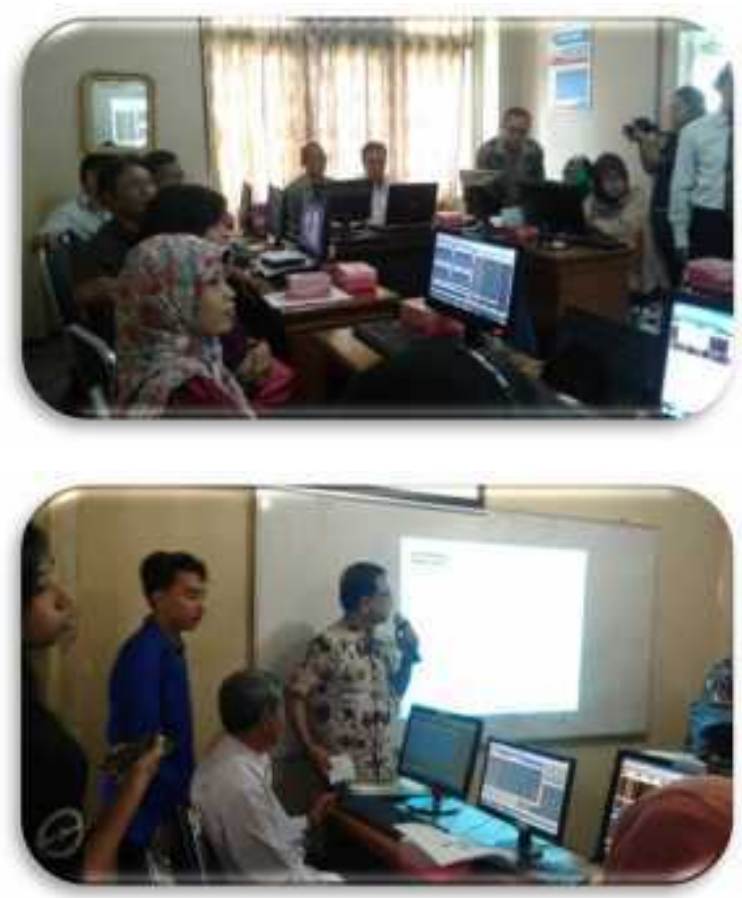

Gambar 6. Dokumentasi pelatihan

Proses pendaftaran investor membutuhkan waktu kurang lebih tiga minggu untuk memiliki Rekening Dana Nasabah (RDN). Sepeluh peserta mendaftarkan diri dan mengisi formulir untuk mendapatkan RDN dari seluruh peserta. Capaian ini diperolah dalam dua minggu setelah pelaksanaan pelatihan untuk menyusun laporan keguatan masyarakat. $23,25 \%$ peserta untuk langsung mendaftarkan diri sebagai investor selama duaminggu pasca pelatihan tersebut adalah capaian output sebesar 76,29\% pendaftaran RDN yang ditargetkan dalam pelaksanaan pelatihan yaitu $30 \%$ dari total peserta atau tiga belas investor baru terbentuk sebagai output utama program pelatihan ini.

Catatan penting lain yang perlu diperhatikan atas hasil pelasanaan pelatihan ini adalah ketertarikan calon investor baru dalam perdagangan saham. Peserta sebagian besar memikili ketertarikan dalam perdagangan saham dalam jangka pendek. Hal tersebut bukan berdasarkan pada pelatihan yang dilakukan dalam jangka pendek (dua hari), akan tetapi berdasarkan hasil diskusi atas orientasi perdagangan yang paling mungkin akan dilakukan oleh pemilik RDN baru. Orientasi tersebut sejalan dengan temuan experimental research pada perilaku investor dan trader saham bahwa keuntungan jangka pendek menjadi hal yang sangat diperhatikan baik oleh pelaku jual beli saham jangka pendek maupun jangka pajang (Khoroshilov, 2013). Lebih lanjut dijelaskan bahwa investor jangka panjang akan mengubah keputusan pertimbangan investasi jangka panjang yang telah ditentukan sebelumnya karena ada memomentum jangka pendek yang dapat dimanfaatkan untuk mendapatkan keuntungan dalam jangka pendek. Strategi tersebut disebut sebagai momentum strategic (Khoroshilov, 2013).

Materi analisis teknikal saham yang dikenalkan oleh peserta dalam pelatihan terdiri dari tiga analisis dasar yang disesdiakan dalam default tampilan aplikasi Relitratde Next G yang dapat diperloleh pada web www.relitrade.com. Aplikasi analisis 
technical tersebut antara lain memahami Candlestick, Simple Moving Average dan Money Flow Index. Fasilitas indikator technical analysis yang disediakan dalam aplikasi Relitrade memiliki kurang lebih 40 indikator. Indikator akan dikenal lebih lanjut saat investor atau trader saat melakukan transaski lebih lanjut secara pribadi berdasarkan frekwensi transaksi yang akan dijalankan sendiri pasca pelatihan. Tampilan analysis technical yang disampaikan oleh peserta dapat ditunjukan pada Gambar 7. Hal tersebut diyakini akan terjadi mempertimbangkan fakta bahwa ketertarikan

) . investor dan trader akan terus mencari tahu indikator baru atau alat prediksi baru untuk mendapatkan pertimbangan yang lebih tepat dalam menentukan keputusan perdagangan saham. Dinamika pasar saham di Indonesia dapat dijelaskan memiliki factor penggerak yang sangat beragam, baik factor fundamental maupun teknikal. Hal tersebut sejalan hasil penelitian yang menggunakan data harian pergerakan harga saham bahwa setiap indeks saham yang berbeda miliki factor penggerak tidak hanya aktifitas perdagangan dalam negeri tetapi juga luar negeri (Murti \& Widyastuti, 2017
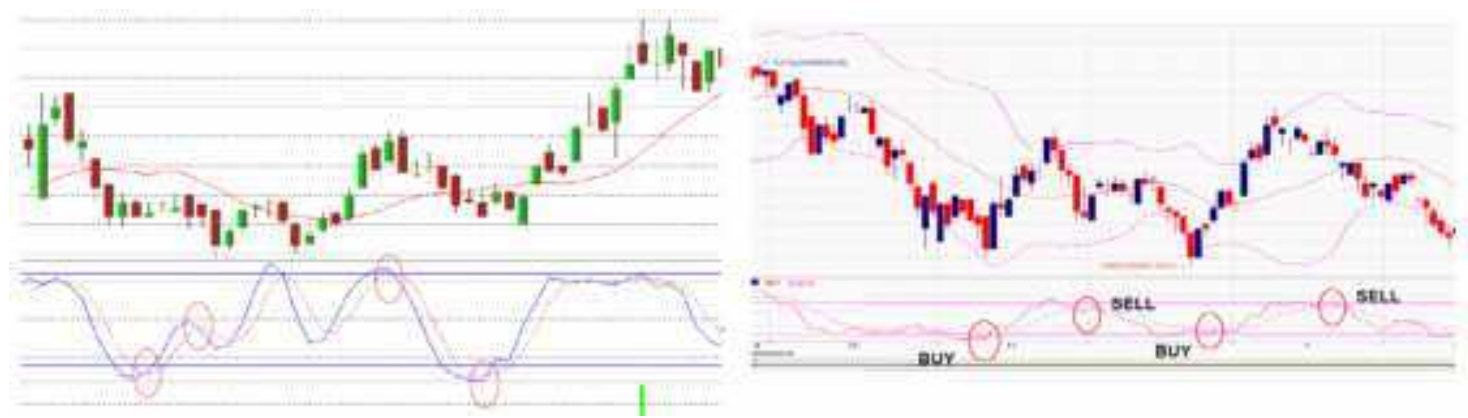

Gambar 5. Tiga analisis teknikal yang disampikan sebagai indicator prediksi pergerakan harga saham Candlestick, Simple Moving Average dan Money Flow Index

Analisis fundamenta disampaikan dalam pelatihan ini. Hal tersebut mempertimbangkan penjelasan tentang analisis fundamental saham bahwa analisa fundmental akan memberikan keyakinan lebih pada keputusan jual beli ataupun investasi saham dalam jangka pendek yang sebelumnya diprediksi berdasarkan analisa teknikal (Desmond, 2011, p. 7). Analisa Fundamental untuk memprediksi pergerakan harga saham diidentifikasi menjadi tiga bagian antara lain 1) analisa makro ekonomi; 2) analisa sektoral dan 3) analisa kinerja emiten (Desmond, 2011, p. 15). Akan tetapi pelatihan focus pada Analisa fundamental makro ekonomi dan sectoral yang dijelaskan sebagai bahan pertimbangan yang seringkali digunakan untuk investasi saham jangka pendek (Murti \& Widyastuti, 2017). Informasi sectoral dan fundamental makro ekonomi ditunjukan dari informasi yang secara rutin tersedia dalam menu news pada aplikasi relitrade Next G dan aplikasi android RTI business.

\section{KESIMPULAN}

Media real trading sebagai fasilitas pelatihan trading dan investasi saham terbukti mencapai target sampai dengan $76 \%$ atas target pendaftaran untuk membentuk Rekening Dana Nasabah (RDN). Hasil ini perlu dipertimbangkan oleh seluruh Galeri Investasi Perguruan Tinggi di Indonesia yang mungkin masih menjalankan proses pelatihan dalam media simulasi. Hasil ini juga penting menjadi perhatian Anggota Bursa (Perusahaan Securitas) dalam menyusun marketing strategic khususnya yang memiliki mitra Galeri Investasi Perguruan Tinggi. Fasilitas khusus yang diberikan Bursa Efek Indonesia (BEI) kepada calon investor melalui jalur perguruan tinggi dengan batas nilai rekening dana investasi yang sangat terjangkau harus dimanfaatkan dalam rangka mempercepat dan mempertahankan pertmbuhan return saham di Indonesia dan meningkatkan kapitalisasi transaksi saham yang dilakukan oleh investor domestic.

\section{DAFTAR PUSTAKA}

Desmond, W. (2011). Analisis Fundamental Saham (edisi kedu). Jakarta: Indonesia: Exceed. Khoroshilov, Y. (2013). Momentum trading 
strategy and investment horizon: an

experimental

study. Journal of Economic Stiudoes, Emerald

Group Publishing Limited, 39(1), 4-12.

Lubis, I. A. (2008). Akuntansi Keperilakuan

(2nd ed.). Jakarta: Indonesia: Salemba Empat.

Murti, N. W., \& Widyastuti, I. (2017).

Merumuskan Pertimbangan Keputusan Cut Gain

dan Cut

Loss Aktifitas Jual Beli Saham Bagi Tipe

Swinger dan Scalper. In Prosiding Seminar

Nasional \& Call for Paper: Hasil

Penelitian dan pengabdian kepada

masyarakat

Universitas Muhammadiyah Semarang (pp. 380389).

Rivai, V. (2005). Manajemen Sumber Daya Manuasia Untuk Perusahaan. Jakarta: PT. Raja

Grafindo Pesada. 